\title{
The hidden role of processors in an individual transferable quota fishery
}

\author{
Danielle N. Edwards ${ }^{1}$ and Evelyn Pinkerton ${ }^{2}$
}

\begin{abstract}
The economically and culturally important Pacific halibut fishery in British Columbia, Canada, managed as an individual transferable quota fishery since 1993, has frequently been held up as an example of management best practices. This narrative of success has continued despite repeated warnings that there are serious problems with the fishery, including processors exerting ever greater control over the fishery, contrary to stated fisheries objectives. Administrative data from federal and provincial data sets were used to consider ownership and control in the halibut fishery, with a focus on processor quota ownership, leasing, and brokerage of leases. The analysis indicated that direct processor ownership of halibut quota, while more than doubling between 1996 and 2016, remains relatively low at less than $10 \%$ of the available quota. Processor control through the leasing of halibut, however, is much higher, accounting for more than half of all halibut quota transfers in 2016. Through strategies such as "holding licences," processors increasingly act as hubs for leasing activity, which has shifted the balance of power in the fishery. This analysis (a) reveals that there is much more processor control than is obvious from a cursory review of ownership, (b) highlights approaches for assessing the level of processor control, and (c) recommends alternative government procedures for improving transparency and evaluating full spectrum outcomes of fisheries management such as equitable distribution of benefits.
\end{abstract}

Key Words: asymmetric information; holding licences; ITQ leasing; oligopsony; transparency

\section{INTRODUCTION}

Fisheries management systems can have many unexpected and often unwelcome impacts, influencing power dynamics, resilience, and overall fisheries success (Foley et al. 2015, Hentati-Sundberg et al. 2015, Stoll et al. 2016). Individual transferable quotas (ITQs) are permits that allow the holder of the ITQ to catch or transfer a share of a total allowable catch (TAC). Individual transferable quotas as a fisheries management system have been widely promoted as a means of achieving positive economic and conservation outcomes (Casey et al. 1995, Grafton 1996, Branch et al. 2006, Grafton et al. 2006a, Grimm et al. 2012). Individual transferable quotas have had a mixed record, however, when the full spectrum of fisheries objectives are considered, particularly related to equitable distribution of benefits, social and economic outcomes for fisheries-dependent communities, resilience, employment, and safety (McCay 1995, 2004, Pálsson and Helgason 1995, Copes and Charles 2004, Carothers et al. 2010, Sumaila 2010, GSGislason \& Associates Ltd 2013, Emery et al. 2014, Pinkerton 2014, Carothers 2015). Concerns over the competitiveness of markets (i.e., monopoly and monopsony issues) and related price manipulation are responsible, in part, for the restrictions on the concentration of quota share ownership that are present in nearly all ITQ fisheries (Anderson 2008).

Analysis of quota lease markets in ITQ fisheries has focused primarily on ownership and related issues of market function (Newell et al. 2005, van Putten and Gardner 2010, van Putten et al. 2011, Ropicki and Larkin 2014, León et al. 2015). Mechanisms for nonownership control in quota markets have been noted (Pinkerton and Edwards 2009) but have not been subject to the same level of scrutiny as ownership mechanisms. At the same time, there is a growing interest in how hidden activities and relationships can exert control over fisheries and lead to unexpected and often negative impacts (Adger et al. 2009, Liu et al. 2013, Galaz et al. 2018).

It is within this context that consideration of the processor control of an ITQ fishery was undertaken. Processor control of fisheries can take the form of (1) limiting opportunities for fishing enterprises to sell product (oligopsony, where there are few buyers and many sellers) and (2) control over fisheries production and access to fishing opportunities (oligopoly, where there are few sellers). The potential for processors to exert control over fisheries through purchase of licences has long been recognized as a potential issue that can lead to market inefficiencies and inequitable distribution of benefits (Clark and Munro 1980, Anderson 1991, National Research Council 1999). In addition to direct ownership of fisheries access rights, processors have other avenues through which they can exert control, including financing, conditional sales agreements, and joint or indirect ownership through which they can dictate the conditions of sale for fishing enterprise catch (Shaffer 1979, Cruickshank 1991, Windle et al. 2008). Concern over processor control in Canada arose historically due to both oligopsony and oligopoly issues (Government of Canada 1976, Pinkerton 1987, Gough 2008). The potential for a small number of processors to exert control that distorts fish prices and disadvantages independent fishing enterprises was the impetus for both the fleet separation and owner-operator policies in Atlantic Canada (Gough 2008). While some processor control mechanisms have been well studied, the potential for processors to exert control over a fishery through a secondary quota leasing market, in which the processor is acting as an intermediary with limited ownership but extensive control of fisheries access rights, has not received the same attention and it is the focus of this paper.

\section{Overview of the British Columbia halibut fishery}

Canada's Pacific halibut fishery is an iconic fishery that is economically and culturally important throughout coastal British Columbia (B.C.). It is one of the highest value fisheries in B.C., with Can\$58.3 million in landed value and Can\$93 million in wholesale value in 2016 (Province of British Columbia 2017). Individual vessel quotas were implemented in the halibut " $L$ " licensed fishery in 1991, followed by limited temporary transferability in 1993 and full temporary and permanent

\footnotetext{
${ }^{1}$ Institute for the Oceans and Fisheries, University of British Columbia, ${ }^{2}$ School of Resource and Environmental Management, Simon Fraser University
} 
transferability in 1999. Temporary transferability refers to leasing of quota annually, and permanent transferability refers to the sale of quota off the licence to another licence. During the period of limited transferability, quota could be transferred only in blocks, with the quota on each licence split into two blocks. A licence with $10,000 \mathrm{lb}(4536 \mathrm{~kg})$ of quota would have two blocks of 5000 $\mathrm{lb}(2268 \mathrm{~kg})$ each, whereas a licence with $40,000 \mathrm{lb}(18,144 \mathrm{~kg})$ of quota would have two blocks of 20,000 lb (9072 kg) each, and these blocks were the minimum unit of transfer. With the introduction of full ("by the pound") transferability, the minimum unit of transfer for quota became $1 \mathrm{lb}$. Unlimited transfers of halibut were permitted, subject to rules on minimum and maximum holdings on the licence (Fisheries and Oceans Canada 2019). There are no restrictions on the number of licences that an individual or company can own.

As part of government efforts to repatriate fisheries access to Indigenous people, the Indigenous communal licence designation was created in the 1990s. Indigenous communal halibut licences are designated as "FL." The Government of Canada has been purchasing "L" licences and quota and transferring them to the "FL" designation since 1997. There were 76 "FL" licences identified in 2018 with combined quota totalling about $16 \%$ of the TAC.

The B.C. halibut fishery is one of the earliest major ITQ fisheries in Canada and has often been referenced as an example of success in fisheries management (Casey et al. 1995, McRae and Pearse 2004, Grafton et al. 2006b, Munro et al. 2009). Fisheries participants and observers have raised concerns, however, about the state of the fishery, citing excessively high lease prices, diminishing financial returns for fishing enterprises, an aging fleet and workforce with little opportunity to attract and retain new entrants, inequitable distribution of benefits, and questionable societal benefits from the resource (Nuu-chah-nulth Tribal Council 2005, United Fishermen and Allied Workers' Union 2005, Ecotrust Canada 2009, Pinkerton and Edwards 2009, Davidson 2010, Canadian Council of Professional Fish Harvesters 2018). The quota leasing system is central to these concerns.

The Government of Canada is mandated to safeguard the interests of Canadians in managing this common pool resource (Fisheries Act, R.S.C. 1985, c. F-14), and fisheries are expected to be managed to meet a full spectrum of social and economic objectives, including benefits to adjacent communities, maintenance of small boat independent fleets, and distributed benefits among participants (Stephenson et al. 2018), as affirmed in legislation (Oceans Act, S.C. 1996, c.31) and policy (Fisheries and Oceans Canada 1999, 2018). Processor ownership of fisheries access privileges has long been recognized as running counter to a number of fisheries management objectives in Canada. In 1977, then Fisheries Minister Romeo LeBlanc, in a speech in Nova Scotia in which he proposed the separation of fishing fleets from processing companies in Atlantic Canada, stated that "Fishermen should own their own boats, and be able to sell fish where they want....Creating a truly independent fleet should improve the efficiency of vessel operations, improve the match of fishing and processing capacity, raise fish prices and fishermen's incomes, increase the fishermen's bargaining power, create a healthier balance of forces in the industry, and invigorate fleet development by the fishermen" (Gough 2008). Concerns about the negative impact of processor ownership of fisheries access led to the establishment of limits on corporate concentration in the B.C. fisheries (Shaffer 1979, Pinkerton 1987, Gough 2008) and owneroperator and fleet separation provisions in other regions of Canada (Gardner 1995, Fisheries and Oceans Canada 2007, Gough 2008, Foley et al. 2015, Barnett et al. 2017). Despite the early recognition of the importance of placing limits on processor ownership, B.C.'s fisheries are some of the only ITQ fisheries in the world without any kind of ownership restrictions. The restrictions on processor control of B.C. fisheries that were in place were never formalized in legislation or regulation, and monitoring and enforcement of these restrictions was abandoned by Fisheries and Oceans Canada (DFO) in the late 1970s, long before the introduction of ITQs to the B.C. groundfish fisheries. The prevailing view in the 1970s was that processor ownership in the B.C. fisheries was minimal (Government of Canada 1976). This stood in contrast to Canada's East Coast fisheries where processor ownership was acknowledged to be significant, and was theorized to be the cause for artificially low prices due to pricing practices of vertically integrated processing companies (Gough 2008). The resulting establishment of fleet separation and owneroperator policies subsequently led to further formalization of ownership and control restrictions in some of Canada's East Coast fisheries (Gough 2008, Barnett et al. 2017).

A further rationale for the absence of processor limitations in the B.C. ITQ fisheries was the perception that ITQs would favor fishing enterprises over processors. Individual transferable quotas were credited with shifting the balance of power between the licence/vessel owner and the processor-buyer, with the licence/ vessel owner appropriating a greater share of the increase in value than the processor (Gislason 2008). What the evaluation by Gislason (2008) failed to account for was the fact that the quota owner and the fishing enterprise are increasingly distinct entities, thereby providing an opening for other actors, namely processors, to exert control through the quota leasing system. Furthermore, oligopsony concerns in B.C. have historically focused on herring and salmon (Pinkerton 1987). Halibut was not considered a concern, given a competitive, noncollusive market while a layup system was in place to spread effort in time and create transparent auction-like conditions in the delivery to processors (Pinkerton 2013). We consider the extent of processor control in an era of quota leasing by processors.

\section{METHODS}

Methods consisted primarily of a detailed analysis of data sets obtained from the management agency DFO, supplemented by the Statistics Canada Inter-Corporate Ownership historical databases, B.C. Provincial Corporate Registry Services records, B.C. provincial processor licence lists, and the Transport Canada vessel registry online query system and historical vessel lists. Methods also included input from B.C. fishermen who were active in the halibut fishery, facilitated through the Canadian Fisheries Research Network - a six-year research network that brought together academia, industry, and government to undertake collaborative research on fisheries in Canada (Thompson et al. 2019). This research was also informed by testimony from B.C. fishermen to the Parliament of Canada House of Commons Standing Committee on Fisheries and Oceans for their study on the regulation of West Coast fisheries. 


\section{Data}

All DFO data used for this research were obtained through access to information requests, which are governed by legislation that requires government departments to release most publicly held data upon request (Access to Information Act, R.S.C. 1985, c. A-1). Only a small portion of the data that is collected for the management and oversight of the B.C. fisheries is made publicly and freely available, namely the licence lists. However, licence list data were unusable for the purposes of this research due to an error in the data set. It consists of current and historical licence holdings and includes the licence type, number, and year; associated vessel; vessel length; and name of the contact owner. At some point between 2008 and 2013, DFO began incorrectly linking licences and vessel ownership for vessel-based licences in this data set by assuming that the most recent owner of the vessel on record was the owner throughout the lifetime of the vessel. This meant that when a vessel was sold to a new owner, that new owner would be recognized as the owner of the vessel and all associated vessel-based licences in the data set for the entire period of the data set, which extended from 1981 to the date the data set was published.

Over a 15-year period, multiple access to information requests for catch, management, and ownership data for B.C. licences and ITQs were made to DFO. Fisheries and Oceans Canada has been inconsistent in its release of data, redacting individual identifiers at times and releasing the requested information in its entirety at other times. Fisheries and Oceans Canada has cited the exemption for confidential information supplied by a third party (exemption 20(1)(b)) to justify redactions. Because the governing legislation had not changed over the period of requests, and the type of information being requested had not changed, this inconsistency can be attributed only to variable interpretation by the department of their legislative requirements to release this information. The main issue seems to be whether the quota allocations and reallocations that DFO regulates and manages, issuing quota each year and processing quota reallocations upon request, constitute government records or third party supplied information, and that the exemption cited is available only for third party-supplied information. Catch data by vessel are indisputably third partysupplied information and are consistently redacted, and thus were not available for the analysis. The three data sets that were available and used for the analysis were (1) licence/vessel ownership, (2) quota transactions administrative records, and (3) quota allocations.

Licensing data by vessel are readily available from DFO, but with limitations. Whereas the "FL" licence is a "party-based licence," meaning that the licence is attached to an individual, the "L" licence is a "vessel-based licence," meaning that the licence is attached to a vessel and not an individual (Fisheries and Oceans Canada 2019). In most cases, the owner of the vessel and the owner of the licence are the same, but when vessel-based licences are leased, the owner on record is a lessee and not the actual licence owner. It is important to note the distinction between licence leasing and quota leasing. Quota leasing is common, and there is an administrative procedure for the management agency to recognize quota leases that does not impact recorded ownership. In contrast, there is no mechanism to "lease" a licence; the licence must be transferred to the lessee vessel in the same way as if the licence were sold, and is regarded as a permanent transfer by the management agency, which then impacts recorded ownership. While quota leasing is common, licence leasing in the halibut fishery is not widespread, although it does occur. Vessel ownership is used in this analysis as a proxy for licence ownership because it is the only available source of ownership data and is consistent with the approach taken by DFO in assigning ownership. The other limitation in assigning ownership relates to multiple owners. The vessel can have multiple owners associated with it, either due to joint ownership of the vessel or licences, to recognize ownership of licences or quota by different owners, or due to financing arrangements. In this analysis, ownership was assigned to the contact owner on record. Secondary ownership by processors based on the full list of owners was also assessed.

The second data set is the quota transfers administrative data. Quota transactions consist of both temporary and permanent transactions. A temporary transfer is a time-limited (in-season) transfer of quota between licences. These transfers can be between licences owned by a single owner or, more commonly, between different owners. In the latter case, the transfer is referred to as a lease. A temporary transfer applies only to the current fishing year, with the quota reverting to its primary licence the following year. Once fished, quota cannot be moved from the licence on which it was fished until the next year. Before it has been fished, quota can be transferred an unlimited number of times, and it is common for quota to be transferred two or three times before it is fished. Temporary transfers are expressed in pounds and permanent transfers can be expressed in either percentage or pounds, although ultimately the purchaser of quota is purchasing a percent of the TAC in each year, not a guaranteed poundage. A complete time series for quota transfers was compiled for 1993 (the beginning of quota transferability) to 2016. The analysis of quota transfers considered only halibut quota from halibut licences. Administrative quota transfers not associated with leasing - e.g., the transfer of quota between DFO-held licences and the 2006 transfers of $10 \%$ of the halibut quota to and from the Pacific Halibut Management Association as per an agreement with the department (Fisheries and Oceans Canada 2006) —were excluded from the analysis. Quota transfers between licences owned by a common owner were also excluded from the analysis of leasing.

The third data set is the initial quota allocation data by licence, which is expressed as a percentage of the commercial halibut TAC. These data have been treated as confidential at different times by DFO but have been released at other times. A complete time series for quota allocation was compiled for 1991 through 2016 using available allocation data and the quota transaction data set, with the exception of 1997, when a different allocation formula was used due to a court case that was later overturned on appeal.

\section{Analysis}

Determination of which vessels fished, in the absence of individual catch records, was based on the presence on the licence of greater than $3500 \mathrm{lb}(1588 \mathrm{~kg})$ of halibut quota at the end of the year. This was determined by the difference between the initial allocation and quota transferred on and off the licence during the year. For the years 2001 through 2006, end-of-year quota on the licence was also available, which was used to validate this approach. A cut-off of $3500 \mathrm{lb}(1588 \mathrm{~kg})$ was chosen based on the lowest amount allocated to a licence in the initial allocation in 1991, verified with industry input that indicated that this 
corresponded to a reasonable minimum catch level of quota that a vessel would need to justify gearing up for a halibut season.

Additional data analysis was undertaken to identify parent company ownership and company affiliations. Processors were identified through a review of the Province of British Columbia list of processor licences, supplemented by a review of trade publications (e.g., Westcoast Fisherman magazine). Building on work to assess corporate concentration in the B.C. salmon and herring fisheries (Haas et al. 2016), the Statistics Canada InterCorporate Ownership records were accessed to identify "parentchild" company relationships for large companies. To examine ownership of the smaller companies, searches of the B.C. Provincial Corporate Registry Services records and the Transport Canada vessel registry were also undertaken. "Parent-child" relationships and affiliations were identified based on cooccurring directors, records of sales, and home addresses on record. For licences with a high degree of quota transfer activity, where affiliations were not obvious from direct or parent ownership, an analysis of the patterns of quota transactions and discussion with active halibut fishermen were undertaken to identify affiliations in three years: 1996, 2006, and 2016.

The quota trading system in 1996, 2006, and 2016 was mapped as social networks to visualize the relationships between the different quota trading entities. Network analysis is a wellestablished field of research that can provide insights into the characteristics of a system of connected actors (Jackson 2008). Network analysis has been used to consider relationships between participants in fisheries (Crona and Bodin 2006, RamirezSanchez and Pinkerton 2009, van Putten and Gardner 2010). In this analysis, connections in the network denote temporary transfers of halibut quota between different actors within the halibut fishery to examine leasing relationships. Quota trading relationships were visualized using the network analysis package "igraph" (Csardi and Nepusz 2006) in R (R Development Core Team 2019).

\section{THE HALIBUT QUOTA LEASING SYSTEM}

The halibut fishery consists of four primary types of actors: fishing enterprise, processor, investor, and Indigenous communal lessor. Within the DFO licence list, there is no classification of licence holders according to these categories. Furthermore, for the B.C. fisheries, DFO does not track affiliations/control due to leasing or other arrangements such as controlling agreements, does not track which companies are processors, and does not distinguish between licence holders that fish (e.g., "fishing enterprises") and licence holders that do not fish (e.g., "investors").

For this analysis, licences were assigned to categories according to the following criteria:

1. Fishing enterprise: includes individuals and companies that can have multiple vessels and licences. The main distinguishing feature of this category is that the enterprise must have at least one vessel that catches halibut in the directed halibut fishery in a given year. The second distinguishing feature is that the enterprise is not classified as a processing company. This includes fishing enterprises that fish communal Indigenous ("FL") licences as well as those that fish regular ("L") halibut licences.
2. Processor: companies that purchase halibut from fishing enterprises to process and sell in the wholesale or retail market. They may own licences, quota, and/or fishing vessels that are fished by a hired skipper. For the purposes of the analysis of quota leasing, licences that are owned by the processor, either wholly or jointly with a fishing enterprise, as well as licences that are "affiliated" with but not owned by processors, either being leased or in some other controlling arrangement, are classified here as processor licences. When considering ownership, only those licences that are directly owned by processors are classified as processor licences.

3. Investor: companies and individuals that own halibut licences and quota that they do not fish themselves and which they lease to others. This includes former fishing enterprises that no longer fish halibut but have retained their halibut quota to lease to others.

4. Indigenous communal lessor: licences held communally by Indigenous organizations (e.g., by an Indigenous government entity, economic development organization, or not-for-profit) that are not fished by them but the quota is leased to fishing enterprises. Most of the licences within this category are "FL" licences. Indigenous individuals who hold regular "L" licences are not included in this category; they are included in either the "fishing enterprise" or "investor" categories depending on whether they fish halibut. Indigenous companies that both hold "FL" licences and process fish are classified in the Indigenous communal lessor category, not the processor category.

Anyone across any of the categories can act as a broker. Independent quota brokerage firms have existed in the B.C. groundfish fishery, and have serviced primarily the groundfish trawl fishery. A separate broker category was not identified for the halibut fishery because the evidence suggests there is only minimal leasing activity within the halibut fishery that could qualify as being carried out by a broker separate from investors, fishing enterprises, and processors. The low penetration of independent brokerages in halibut can be attributed to (1) relatively high transaction costs for using a brokerage company, (2) established relationships, particularly between processors and investors, and processors and fishermen, and (3) the widely held view that processors are willing to pay higher lease prices than fishermen, and thus are a more attractive target for investors (Pinkerton and Edwards 2009).

\section{Extent of leasing}

By the mid-2000s, nearly every licence in the halibut fishery engaged in leasing to some extent (Fig. 1). This can be attributed to (1) the minimum permanent quota holdings requirement for halibut licences (at least $0.01149 \%$ of the TAC on each licence, equivalent to $706 \mathrm{lb}[320 \mathrm{~kg}]$ in 2016) (Fisheries and Oceans Canada 2019), (2) high quota lease value (Can\$8.40/lb in 2016) (Simpson 2017), (3) a strong leasing market, and (4) low levels of quota ownership by many fishing enterprises. In 2016, investors owned $43 \%$ of the halibut quota, up from $0 \%$ in 1991 and $23 \%$ in 1996 (Edwards and Pinkerton 2019a). In contrast, owneroperators went from owning $90 \%$ of quota in 1991 to $15 \%$ in 2016. 
Fig. 1. The percentage of halibut licences involved in temporary quota transactions each year.

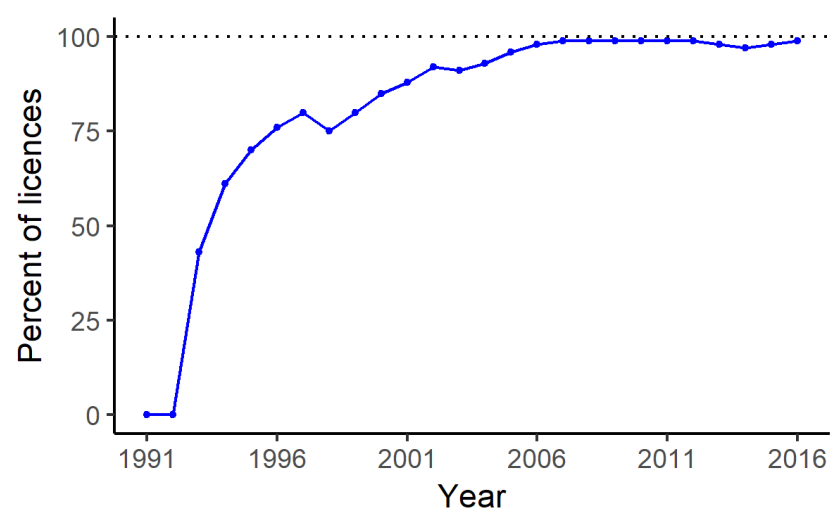

\section{PROCESSOR OWNERSHIP AND CONTROL}

If one looks only at licence and quota ownership based on the DFO licensing database, there is little evidence of processor control or changes in processor ownership over the last 20 years. Based on reported ownership, the maximum percent of halibut quota owned by a single entity in 2016 was $1.95 \%$ of the TAC, which increased to $3.35 \%$ when parent ownership was considered. While not an insignificant amount of quota, having a lease value of Can\$1.7 million in 2016 and a current market value of more than Can\$20 million, this level of ownership is not on its own indicative of high corporate concentration. When ownership by processors as a whole was considered, ownership steadily increased but was still less than $10 \%$ in 2016 (Fig. 2). Processors as declared secondary owners of licences was also considered. When secondary ownership was included, processor ownership nearly doubled in 1996 but was of diminishing importance in later years. In 2006, processors had ownership interests in vessels associated with 30 halibut licences, for which they were the primary contact owner of 18 and secondary owners of 12 . In 2016 , the number of these licences increased to 31 , but processors were secondary owners of only 6 . Secondary ownership should be interpreted with caution, however, as the nature of the secondary ownership by the processor is not known and could be anything from a loan against the vessel, or ownership of another licence on the vessel, to full ownership of the halibut licence and quota. Where processor control becomes more evident is in an examination of quota leasing, particularly the use of holding licences.

An approach that has gained prominence in the halibut fishery is the use of holding licences by processors, which are used to hold quota in-season. For example, a processor may lease (for a nominal price) one of the more than 200 halibut licences that are not being fished, and use it to hold quota temporarily when acting as a broker between lessors and lessees of halibut quota. These holding licences have a high poundage of quota transferred on and off, and the licences are typically not fished themselves. These licences, which can be either already owned by the processor or leased by the processor each year, serve to consolidate control by processors, thereby enabling them to lease in quota early in the season, take possession of it on a licence they control, and then lease it back out to fishermen through the season when fish is delivered to them. The previously dominant practice was for fishing enterprises to lease directly from lessors or for processors to arrange the quota lease and transfer the quota directly from the lessor to the fishing enterprise. Even when the processor was arranging the lease, this approach afforded information to the fishing enterprise on the source of the quota and, to some extent, the amount of quota leased. The use of holding licences impedes transparency in the quota leasing system by reducing information available to fishing enterprises about the original source of the quota that they are leasing. They know only that it has been transferred from the processor's holding licence and are not provided any indication of how much quota the processor has leased or from whom or at what price.

Fig. 2. Processor quota ownership expressed as a percentage of total allowable catch for both direct ownership and ownership where the processor is listed as a secondary owner, and processor control over leasing as measured as quota transfers through processor owned and affiliated licences as a percentage of total quota temporarily transferred in the year, for 1996 , 2006, and 2016.

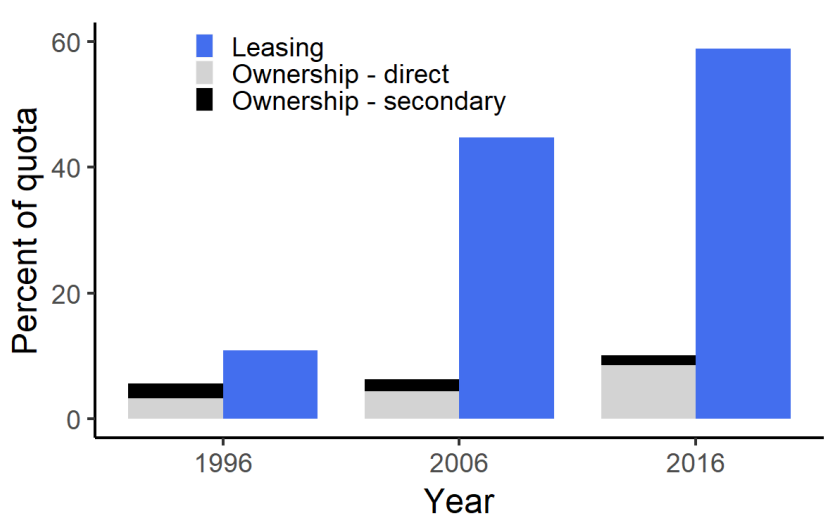

The use of holding licences by processors has evolved over time. There was one processor-controlled holding licence identified in 2006, which had more than 2 million pounds $(907,185 \mathrm{~kg}$ ) of quota transfers on and off the licence that year. The quota transfers through this one holding licence represented control over about 1 million pounds $(453,592 \mathrm{~kg})$ of quota, equivalent to about $9 \%$ of the TAC in 2006 . The difference between the quota transfers ( 2 million pounds [907,185 kg]) and the quota involved (a maximum of 1 million pounds [453,592 kg]) is due to the fact that for a holding licence, quota leasing includes both inward and outward transfers, with quota leased from quota owners and transferred onto the holding licence and then leased out again to fishing enterprises and transferred off the holding licence to the licence used to fish the quota. As evident from analysis of the quota transfers data set, the practice of using holding licences became more widespread and sophisticated in the years following as other processors adopted the practice. By 2016, there were nine licences with transfers of more than $200,000 \mathrm{lb}(90,718 \mathrm{~kg})$ of quota each while not being fished in the year, with processors 
managing multiple holding licences to provide more flexibility, given individual licence cap limitations of $1 \%$ of the TAC. The same processor with the 2 million pounds $+(907,185 \mathrm{~kg}+)$ holding licence from 2006 had holding licence leases representing up to about $9 \%$ of the TAC in 2016 as well, only over multiple licences. This same processor had declared ownership of less than $2 \%$ of the halibut quota. The second most active processor in 2016, with quota leases corresponding to about $7.5 \%$ of the halibut TAC, did not own any halibut licences or quota. While the practice of leasing through holding licences has become more widespread, processor leasing continues to be concentrated: the top four processors in 2016 were responsible for more than $80 \%$ of the quota holding licence leasing by processors. These processors were all well established, having operated in the B.C. fisheries for decades.

Processor penetration into the overall halibut quota leasing system, as measured based on quota transactions that involved a processor owned or affiliated licence, is significant, reaching $59 \%$ of temporary quota transfers by weight in 2016. Quota was predominantly leased from investors, although Indigenous communal quota lessors, other processors, and fishing enterprises also leased quota to processors (Fig. 3). In Fig. 3, the nodes (circles) represent individual quota traders, and the size of the nodes is indicative of the total poundage of quota transferred by the entity in that year, inclusive of both inward and outward trades. Nodes that do not connect to others are cases where no quota was traded or where quota was traded only within a fishing enterprise or to licences outside the directed halibut fishery. The total poundage transferred decreased from 2006 to 2016 because of an almost $50 \%$ drop in the TAC. Total temporary quota transfer activity of halibut, inclusive of all licences, increased over this period, both in terms of percent of TAC $(79 \%$ of TAC in 2006 to $108 \%$ in 2016) and in the total number of temporary quota transfers (779 in 2006 and 911 in 2016). Consideration of direct ownership and leasing through holding licences was possible only through the amalgamation of a number of different data sources from DFO and the B.C. provincial government, combined with information from fishery participants. This information is not currently tracked by DFO and it is not readily available. The extent of processor control presented here represents only a minimum estimate, given limitations of both the quota transfer data that are released and the data that are collected in the administration of quota transfers by the management agency. Processors continue to lease quota that they transfer directly from the original lessee to the fishing enterprise licence, in which cases processor involvement is not evident from the information provided within the quota transfers administrative data received from DFO.

\section{POWER DYNAMICS IN THE QUOTA LEASING RELATIONSHIP}

Processors are able to readily fill a brokerage role in the quota leasing system in large part because of their access to capital. For fishing enterprises that do not own appreciable amounts of halibut quota, which is now the majority of the vessels that are fishing, it is often a financial struggle to operate (Edwards and Pinkerton 2019b). About 70\% of fishing enterprises in 2016 fished at least $20,000 \mathrm{lb}(9072 \mathrm{~kg})$ of halibut quota. The lease cost for $20,000 \mathrm{lb}(9072 \mathrm{~kg})$ of halibut quota is estimated to have been as high as Can $\$ 168,000$ in 2016 (Simpson 2017). Most halibut fishing enterprises do not have access to this amount of capital to lease quota at the beginning of the season. Financial institutions in B.C. will not loan against quota, particularly for an in-season lease, unless other more tangible assets are used as collateral, and even then, at a high cost. This puts leasing of any larger amount of quota at the beginning of the season beyond the reach of most fishing enterprises, and indeed, even smaller processors looking to enter the business. The requirement to access significant capital strongly favors incumbents that are already in a good financial position and have a business that accommodates large fluctuations in cash flow through the year, which characterizes successful, established processors but not most fishing enterprises. At the same time, quota owners have expressed a preference to lease to processors, with the prevailing view in the industry that processors are willing to pay higher lease prices for quota than fishermen, and that there is less social pressure on owners to lower their lease price when dealing with processors (Pinkerton and Edwards 2009).

Fig. 3. The quota trading network in the British Columbia halibut fishery in 1996, 2006, and 2016, as characterized by temporary quota transactions between quota traders.
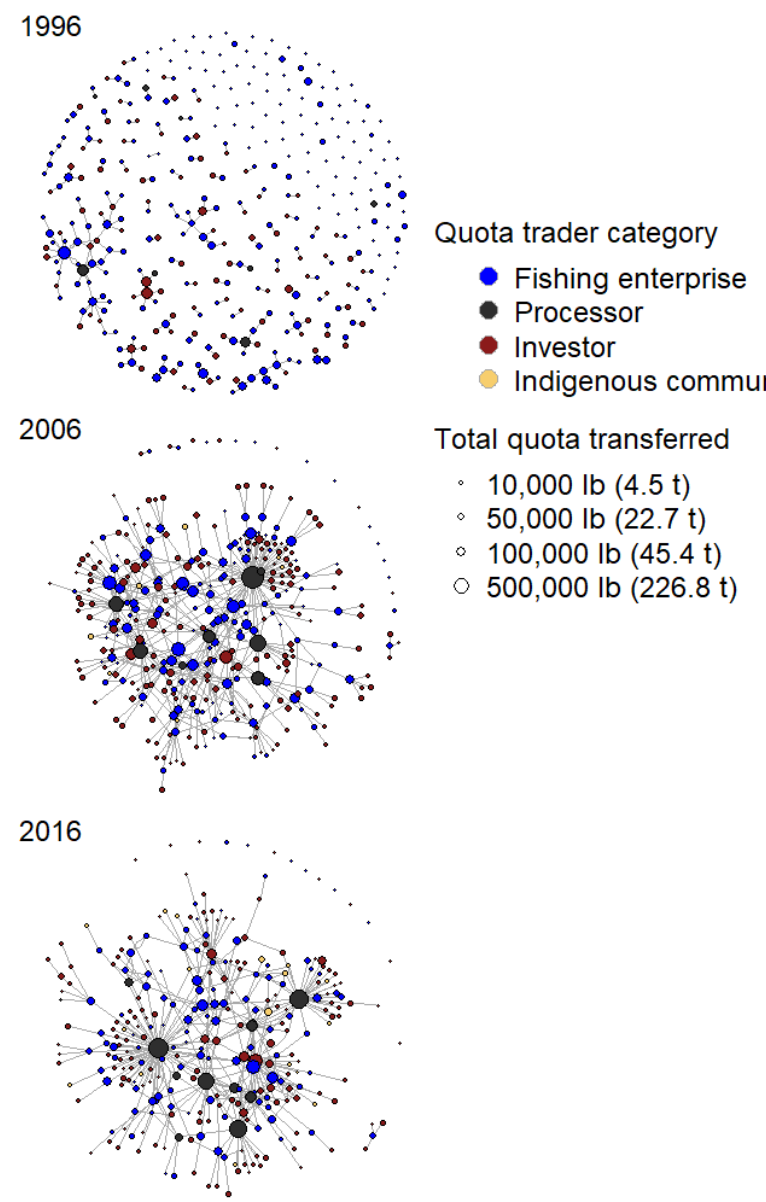

Access to capital is but one aspect of the power imbalance between fishing enterprises and processors. In part because of their greater access to capital, processors are in a preferred position to lease quota from investors, who have emerged as a major ownership 
class under ITQs in the halibut fishery (Edwards and Pinkerton 2019a). This then allows the processors to establish relationships with the investors that further entrenches their access to quota over time and control of the quota market. These processorinvestor relationships have been identified by fishery participants as an obstacle to more independent fishing enterprises (Parliament of Canada 2019). These relationships also afford processors access to information about who holds quota, in what amounts, and at what price they will lease it out, which, unlike regulated trading markets, is information that is not readily available to most other participants in the quota market.

As processors gain greater control over leasing, industry norms related to information sharing about landed value and lease fees have also shifted. When processors provide access to most of the quota that a vessel fishes, the fish slip that records the sale of fish to the processor no longer reflects the actual landed price or the lease price for the quota; instead, it provides only the after-lease price. The fish slip is a record of the landing, required by DFO, which must list the buyer, seller, weight, and price for each species and grade of fish sold. The after-lease price is the price received by the lessee fishing enterprise - the difference between the landed price and the lease price, as well as any fees or adjustments added in by the processor. For fishing enterprises, the listing of only the after-lease price on the fish slip means that they do not know what lease price they are paying per pound or what their catch is worth at the dock. They only know what they are receiving as the difference of the two. Because fishing enterprises must sell to the processor that is providing access to the quota needed to cover the catch, and basic information such as landed price is often not provided, fishing enterprises are at a distinct disadvantage in any attempt to better their position and seek higher prices.

Processors have a strong incentive to lease quota preseason as a means of securing supply of halibut deliveries during the season, with most of the risk borne by fishing enterprises. The processor is able, in most instances, to pass on the full costs of the lease to the fishing enterprise while also guaranteeing that the lessee will deliver their catch to the processor. While indications are that competition between processors for quota remains very high, evidence suggests that competition to attract and retain fishing enterprises as suppliers of the actual catch is low. Despite steep increases in landed price of halibut since 2010 (Province of British Columbia 2017), the average after-lease price has been stable to trending downward (Edwards 2019). Quota leasing is not without some risk for processors, particularly when leasing large amounts of quota preseason at prices that assume that the wholesale market in the coming year will support the lease price. The risk to processors is ameliorated, however, by the ability of processors to adjust the after-lease price to make up for lower-than-expected wholesale prices. Given the limited information available to lessee fishing enterprises, they do not know the components of the afterlease price they are receiving - if it is the landed price less the lease price paid, or if lease losses or management or financing charges are included. Adjustments to the after-lease price are bounded to some extent. Even though fishing enterprises are highly competitive for access to quota to fish, few fishing enterprises, when given the choice, will fish if short-term costs, such as bait, fuel, and monitoring costs, are not being covered (Edwards and Pinkerton 2019b). Not all fishing enterprises have the choice, however, as fishing enterprises may fish at a loss if the enterprise risks losing future access to quota if they do not fish (Parliament of Canada 2019).

\section{THE ROLE OF GOVERNMENT IN MANAGING MARKETS}

The management agency has taken on a strictly administrative role in the quota market, processing quota transfer requests. With no public quota registry or management of the quota leasing system, quota leasing operates in a black box that is opaque to most fishing enterprises and the management agency, and is without official oversight or influence. Fisheries and Oceans Canada has characterized the quota leasing system as "willing buyer, willing seller" (Mawani 2009) and has absented itself entirely from a role in overseeing those relationships or in mitigating the potential of the system to violate management objectives.

Governments in a market economy are, at a minimum, expected to intervene in cases of market failure arising from externalities, imperfect information, or market control (Smith 1776, Stiglitz 1993, Nayak 1996, Tanzi 2011). A minimalist approach to government intervention often focuses on research, education, and developing market mechanisms to improve information availability, counter monopolies or oligopolies, and correct externalities such as ecosystem degradation (e.g., pollution, habitat destruction). A minimalist approach to government intervention has been criticized for not adequately accounting and adjusting for disruptions in society and the economy (Tanzi 2011). An alternative view has been posited that identifies an important role for government in leading transformational change (Mazzucato 2015). Under either scenario, there is a clear role for government to intervene in the B.C. halibut quota lease market. At the very least, there is a strong rationale for government to undertake research and investigations into the state of the quota market and address the asymmetric information and capital availability issues that are leading to uninformed decision-making and price distortions that challenge the viability, stability, and independence of the fleet (Edwards and Pinkerton $2019 b$ ). Stabilizing the quota market, instituting rules and procedures to create transparency, including new reporting requirements for tracking ownership and leasing, and preventing price distortions are further actions that may be expected of government that is seeking to prevent or correct market failure.

There is extensive literature on the importance of the availability of information to all parties involved in negotiation for effective and efficient market function (Coase 1960, Stigler 1966, Stiglitz 2000, Holland et al. 2015). The lack of transparency and limited data collection by the management agency to track ownership and control of a public resource is an issue that has been previously highlighted for the B.C. salmon and herring fisheries (Haas et al. 2016) and groundfish fisheries (Pinkerton and Edwards 2009). This situation is exacerbated by the corporate reporting requirements in Canada. There are no requirements for public reporting of private company shareholders, there are no requirements to disclose beneficial ownership when creating a corporation (Meunier 2018), and anonymous shell companies can be readily established (Sharman 2011). Federal tracking and reporting of intercorporate ownership through Statistics Canada reaches only the very largest fishing companies. The B.C. provincial government requires B.C. registered companies to list 
only directors and not shareholders in annual report filings, and does not make information on directors or other basic information such as incorporation date freely available or readily searchable. Rather, the provincial government requires payment of a fee to access the corporate history, such as it is, for each corporation. The practice of DFO in not tracking licence ownership of vessel-based licences is a further obstacle to understanding, monitoring, and reporting conditions in the B.C. fishery.

\section{CONCLUSION}

There has been a marked change in the role of processors over time as the number of quota transactions has increased and processors have exerted a more pronounced influence in the quota leasing market. Despite their hidden role in the fishery, directly owning less than $10 \%$ of halibut quota, processors have considerable influence through their role as quota lessees and lessors by controlling more than $50 \%$ of temporary quota transfers by poundage. This influence consolidated in the period between 2006 and 2016, with processors becoming the primary hubs for quota leasing. The central role of processors in controlling the leasing market has shifted the balance of power in the fishery to disadvantage fishing enterprises, particularly those that are in the position of having to lease the majority of their quota, which is a steadily increasing proportion of fishing enterprises. This has implications for the ability of fishing enterprises to negotiate for higher prices, and thus for the distribution of benefits in the fishery. Established processors have been controlling access to enough of the quota market through leasing to limit the pool of buyers, thus gaining the ability to control the market and, by extension, the after-lease price received by fishing enterprises. This raises concerns about oligopsony and the competitiveness of the raw halibut market.

Despite data limitations, analysis and determination of the minimum level of processor ownership and control is possible, as was demonstrated with this analysis. Indeed, the management agency's preferential access to data would enable a more complete consideration of the processor control issue. For example, a more direct evaluation of oligopsony in the halibut fishery would be possible with access to data that are treated as confidential by the management agency, notably through examination of fish slips to identify more completely the relationships between fishing enterprises and processors and to determine what proportion of halibut deliveries and the associated benefits the dominant processors receive. There is also an opportunity for collaboration across the provincial and federal governments to combine their respective data sets to better understand ownership and control within the B.C. fisheries.

An improved understanding of how processors can exert control over an individual transferable quota fishery offers lessons for implementation and management of ITQ fisheries globally. As interest in full spectrum evaluation of fisheries increases, the need to address a broad range of issues (e.g., distribution of benefits, power dynamics, and resilience) and to consider the levers of control and influence within fisheries systems have become increasingly important. Better understanding of how the fishery operates and the power relationships across the fishery could also directly inform the development of fisheries and rural economic development policy in Canada. Fisheries, as a common pool resource and economic driver for coastal communities in Canada, are meant to contribute to objectives for economic prosperity and social inclusion. Improved access to fisheries by coastal and Indigenous communities has been identified as a policy imperative for B.C. (Bennett et al. 2018). Despite a widely held view that, once implemented, ITQs are nearly impossible to change, there are mechanisms available to the management agency and others to retroactively address processor and corporate control in ITQ fisheries (Edwards and Edwards 2017), which would be aided by a full understanding of conditions in the fishery. The B.C. halibut fishery is an example of asymmetric information between parties and poorly functioning markets that act as impediments to informed management and business decision-making. Further analysis is needed, warranting both new approaches to data collection by the management agency and consideration of existing data, either conducted and reported by the management agency or by making heretofore restricted data available to external researchers and stakeholders.

Responses to this article can be read online at: http://www.ecologyandsociety.org/issues/responses. php/11148

\section{Acknowledgments:}

This paper is based on a research project supported by the Natural Science and Engineering Research Council of Canada (NSERC) funded Canadian Fisheries Research Network (CFRN). The first author thanks the fishery participants who shared their experiences to inform this research and her graduate supervisor Villy Christensen for his support in completing this research.

\section{LITERATURE CITED}

Adger, W. N., H. Eakin, and A. Winkels. 2009. Nested and teleconnected vulnerabilities to environmental change. Frontiers in Ecology and the Environment 7(3):150-157. https://doi. org/10.1890/070148

Anderson, L. G. 1991. A note on market power in ITQ fisheries. Journal of Environmental Economics and Management 21 (3):291-296. https://doi.org/10.1016/0095-0696(91)90032-E

Anderson, L. G. 2008. The control of market power in ITQ fisheries. Marine Resource Economics 23(1):25-35. https://doi. org/10.1086/mre.23.1.42629600

Barnett, A. J., R. A. Messenger, and M. G. Wiber. 2017. Enacting and contesting neoliberalism in fisheries: the tragedy of commodifying lobster access rights in Southwest Nova Scotia. Marine Policy 80:60-68. https://doi.org/10.1016/j.marpol.2016.03.002

Bennett, N. J., M. Kaplan-Hallam, G. Augustine, N. Ban, D. Belhabib, I. Brueckner-Irwin, A. Charles, J. Couture, S. Eger, L. Fanning, P. Foley, A. M. Goodfellow, L. Greba, E. Gregr, D. Hall, S. Harper, B. Maloney, J. McIsaac, W. Ou, E. Pinkerton, D. Porter, R. Sparrow, R. Stephenson, A. Stocks, U. R. Sumaila, T. Sutcliffe, and M. Bailey. 2018. Coastal and Indigenous community access to marine resources and the ocean: a policy imperative for Canada. Marine Policy 87:186-193. https://doi.org/10.1016/j. marpol.2017.10.023 
Branch, T. A., K. Rutherford, and R. Hilborn. 2006. Replacing trip limits with individual transferable quotas: implications for discarding. Marine Policy 30(3):281-292. https://doi.org/10.1016/ j.marpol.2004.12.003

Canadian Council of Professional Fish Harvesters. 2018. Fisheries seasonality and the allocation of labour and skills: labour market information study. Gatineau, Quebec, Canada. http:// www.fishharvesterspecheurs.ca/product/fisheries-seasonality-andallocation-labour-and-skills

Carothers, C. 2015. Fisheries privatization, social transitions, and well-being in Kodiak, Alaska. Marine Policy 61:313-322. https:// doi.org/10.1016/j.marpol.2014.11.019

Carothers, C., D. K. Lew, and J. Sepez. 2010. Fishing rights and small communities: Alaska halibut IFQ transfer patterns. Ocean \& Coastal Management 53(9):518-523. https://doi.org/10.1016/j. ocecoaman.2010.04.014

Casey, K. E., C. M. Dewees, B. R. Turris, and J. E. Wilen. 1995. The effects of individual vessel quotas in the British Columbia halibut fishery. Marine Resource Economics 10(3):211-230. https://doi.org/10.1086/mre.10.3.42629588

Clark, C. W., and G. R. Munro. 1980. Fisheries and the processing sector: some implications for management policy. Bell Journal of Economics 11(2):603-616. https://doi.org/10.2307/3003382

Coase, R. H. 1960. The problem of social cost. Journal of Law \& Economics 3:1-44. https://doi.org/10.1086/466560

Copes, P., and A. Charles. 2004. Socioeconomics of individual transferable quotas and community-based fishery management. Agricultural and Resource Economics Review 33(2):171-181. https://doi.org/10.1017/S106828050000575X

Crona, B., and Ö. Bodin. 2006. What you know is who you know? Communication patterns among resource users as a prerequisite for co-management. Ecology and Society 11(2):7. https://doi. org/10.5751/ES-01793-110207

Cruickshank, D. 1991. A commission of inquiry into licensing and related policies of the Department of Fisheries and Oceans. Fleming Printing Ltd., Victoria, British Columbia, Canada.

Csardi, G., and T. Nepusz. 2006. The igraph software package for complex network research:1695.

Davidson, A. 2010. The cost-benefit ledger of quota leasing. Marine Policy 34(5):1115-1116. https://doi.org/10.1016/j. marpol.2010.01.013

Ecotrust Canada. 2009. Briefing: a cautionary tale about ITQ fisheries in BC fisheries. Vancouver, British Columbia, Canada. http://ecotrust.ca/wp-content/uploads/2015/02/ITQ_CautionaryTale FINAL.pdf

Edwards, D. N. 2019. Price, investment and leasing data for the British Columbia ITQ halibut fishery. Mendeley Data V1. https:// doi.org/10.17632/n77bhwyp3y. 1

Edwards, D. N., and D. G. Edwards. 2017. Licence Banks as a tool to mitigate corporate control of fisheries: a British Columbia groundfish example. Marine Policy 80:141-146. https://doi. org/10.1016/j.marpol.2016.11.006
Edwards, D. N., and E. W. Pinkerton. 2019a. Rise of the investor class in the British Columbia Pacific halibut fishery. Marine Policy, in press.

Edwards, D. N., and E. W. Pinkerton. 2019b. Priced out of ownership: quota leasing impacts on the financial performance of owner-operators. Working Paper \#2019 - 03, University of British Columbia, Vancouver, British Columbia, Canada. http:// fisheries.sites.olt.ubc.ca/files/2019/06/Working-Paper-2019-03-PricedOut.pdf

Emery, T. J., K. Hartmann, B. S. Green, C. Gardner, and J. Tisdell. 2014. Fishing for revenue: how leasing quota can be hazardous to your health. ICES Journal of Marine Science 71(7):1854-1865. https://doi.org/10.1093/icesjms/fsu019

Fisheries and Oceans Canada. 1999. Pacific Region 1999 Halibut Integrated Fisheries Management Plan.

Fisheries and Oceans Canada. 2006. Pacific Region 2006/2007 Integrated Fisheries Groundfish Management Plan.

Fisheries and Oceans Canada. 2007. Policy for preserving the independence of the inshore fleet in Canada's Atlantic Fisheries. http://www.dfo-mpo.gc.ca/reports-rapports/regs/piifcaf-policy-politiquepifpcca-eng.htm

Fisheries and Oceans Canada. 2018. Pacific Region Groundfish Integrated Fisheries Management Plan 2018.

Fisheries and Oceans Canada. 2019. Commercial fisheries licensing rules and policies reference document: Pacific Region. http://www.pac.dfo-mpo.gc.ca/fm-gp/licence-permis/docs/commerciallicence-permis-ref/commercial-licence-permis-ref-eng.pdf

Foley, P., C. Mather, and B. Neis. 2015. Governing enclosure for coastal communities: social embeddedness in a Canadian shrimp fishery. Marine Policy 61:390-400. https://doi.org/10.1016/j. marpol.2014.11.009

Galaz, V., B. Crona, A. Dauriach, J.-B. Jouffray, H. Österblom, and J. Fichtner. 2018. Tax havens and global environmental degradation. Nature Ecology \& Evolution 2(9):1352-1357. https:// doi.org/10.1038/s41559-018-0497-3

Gardner, M. 1995. Input controls vs. rights-based management: the political economy of fisheries management in Atlantic Canada. Aquatic Living Resources 8(3):267-277. https://doi. org/10.1051/alr:1995026

Gislason, G. S. 2008. Employment impacts of ITQ fisheries in Pacific Canada. Department of Fisheries and Oceans, Ottawa, Ontario, Canada.

Gough, J. 2008. Managing Canada's fisheries: from early days to the year 2000. Les Éditions du Septentrion, Sillery, Quebec, Canada.

Government of Canada. 1976. Policy for Canada's commercial fisheries. Department of the Environment, Fisheries and Marine Service, Ottawa, Ontario, Canada. http://www.dfo-mpo.gc.ca/ Library/293.pdf

Grafton, R. Q. 1996. Individual transferable quotas: theory and practice. Reviews in Fish Biology and Fisheries 6(1):5-20. https:// doi.org/10.1007/BF00058517 
Grafton, R. Q., R. Arnason, T. Bjørndal, D. Campbell, H. F. Campbell, C. W. Clark, R. Connor, D. P. Dupont, R. Hannesson, R. Hilborn, J. E. Kirkley, T. Kompas, D. E. Lane, G. R. Munro, S. Pascoe, D. Squires, S. I. Steinshamn, B. R. Turris, and Q. Weninger. 2006a. Incentive-based approaches to sustainable fisheries. Canadian Journal of Fisheries and Aquatic Sciences 63 (3):699-710. https://doi.org/10.1139/f05-247

Grafton, R. Q., H. W. Nelson, and B. R. Turris. 2006b. How to resolve the class II common property problem? The case of British Columbia's multi-species groundfish trawl fishery. In T. Bjørndal, D. Gordon, R. Arnason, and U. R. Sumaila, editors. Advances in the economics of the fishery: festschrift in honour of Professor $G$. R. Munro. Australian National University Economics and Environment Network Working Paper EEN0506, Oxford, UK.

Grimm, D., I. Barkhorn, D. Festa, K. Bonzon, J. Boomhower, V. Hovland, and J. Blau. 2012. Assessing catch shares' effects evidence from Federal United States and associated British Columbian fisheries. Marine Policy 36(3):644-657. https://doi. org/10.1016/j.marpol.2011.10.014

GSGislason \& Associates Ltd. 2013. The BC fishing industry labour market information. BC Seafood Alliance.

Haas, A. R., D. N. Edwards, and U. R. Sumaila. 2016. Corporate concentration and processor control: insights from the salmon and herring fisheries in British Columbia. Marine Policy 68:83-90. https://doi.org/10.1016/j.marpol.2016.02.019

Hentati-Sundberg, J., J. Hjelm, W. J. Boonstra, and H. Österblom. 2015. Management forcing increased specialization in a fishery system. Ecosystems 18(1):45-61. https://doi.org/10.1007/ $\underline{\mathrm{s} 10021-014-9811-3}$

Holland, D. S., E. Thunberg, J. Agar, S. Crosson, C. Demarest, S. Kasperski, L. Perruso, E. Steiner, J. Stephen, A. Strelcheck, and M. Travis. 2015. US catch share markets: a review of data availability and impediments to transparent markets. Marine Policy 57:103-110. https://doi.org/10.1016/j.marpol.2015.03.027

Jackson, M. O. 2008. Social and economic networks. Princeton University Press, Princeton, New Jersey, USA.

León, R., C. Gardner, I. van Putten, and K. Hartmann. 2015. Changes in the lease and permanent sale quota markets of a rock lobster fishery in response to stock abundance. ICES Journal of Marine Science 72(5):1555-1564. https://doi.org/10.1093/icesjms/ $\underline{\text { fsu246 }}$

Liu, J., V. Hull, M. Batistella, R. DeFries, T. Dietz, F. Fu, T. W. Hertel, R. C. Izaurralde, E. F. Lambin, S. Li, L. A. Martinelli, W. J. McConnell, E. F. Moran, R. Naylor, Z. Ouyang, K. R. Polenske, A. Reenberg, G. de M. Rocha, C. S. Simmons, P. H. Verburg, P. M. Vitousek, F. Zhang, and C. Zhu. 2013. Framing sustainability in a telecoupled world. Ecology and Society 18(2):26. https://doi. org/10.5751/ES-05873-180226

Mawani, T. 2009. Evaluation of the commercial groundfish integration pilot program in British Columbia. Thesis. Royal Roads University, Victoria, British Columbia, Canada.

Mazzucato, M. 2015. From market fixing to market-creating: a new framework for economic policy. SSRN Scholarly Paper, Social Science Research Network, Rochester, New York, USA. https:// papers.ssrn.com/abstract $=2744593$ https://doi.org/10.2139/ssrn.2744593
McCay, B. J. 1995. Social and ecological implications of ITQs: an overview. Ocean \& Coastal Management 28(1-3):3-22. https:// doi.org/10.1016/0964-5691(96)00002-6

McCay, B. J. 2004. ITQs and community: an essay on environmental governance. Agricultural and Resource Economics Review 33(2):162-170. https://doi.org/10.1017/S1068280500005748

McRae, D. M., and P. H. Pearse. 2004. Treaties and transition: towards a sustainable fishery on Canada's Pacific Coast. Vancouver and Victoria, British Columbia, Canada. https://waves-vagues. dfo-mpo.gc.ca/Library/280188.pdf

Meunier, D. 2018. Hidden beneficial ownership and control: Canada as a pawn in the global game of money laundering. SSRN Scholarly Paper, Social Science Research Network, Rochester, New York, USA. https://papers.ssrn.com/abstract=3246098 https:// doi.org/10.2139/ssrn.3246098

Munro, G. R., B. Turris, C. W. Clark, U. R. Sumaila, and M. Bailey. 2009. Impacts of harvesting rights in Canadian Pacific fisheries. Statistical and Economic Analysis Series No. 1-3, Fisheries and Oceans Canada, Ottawa, Ontario, Canada. http:// science-catalogue. canada. ca/record $=4016293 \&$ searchscope $=06$

National Research Council. 1999. Sharing the fish: toward a national policy on individual fishing quotas. National Academy, Washington, DC, USA.

Nayak, P. B. 1996. The state and the market. Economic and Political Weekly 31(4):PE18-PE22.

Newell, R. G., J. N. Sanchirico, and S. Kerr. 2005. Fishing quota markets. Journal of Environmental Economics and Management 49(3):437-462. https://doi.org/10.1016/j.jeem.2004.06.005

Nuu-chah-nulth Tribal Council. 2005. Pilot integration proposal Phase I response to the CGIAC.

Pálsson, G., and A. Helgason. 1995. Figuring fish and measuring men: the individual transferable quota system in the Icelandic cod fishery. Ocean \& Coastal Management 28(1-3):117-146. https:// doi.org/10.1016/0964-5691(95)00041-0

Parliament of Canada. 2019. Regulation of the West Coast fisheries. Ottawa, Ontario, Canada. https://www.ourcommons. ca/Committees/en/FOPO/StudyActivity?studyActivityId=10380159

Pinkerton, E. 2013. Alternatives to ITQs in equity-efficiencyeffectiveness trade-offs: how the lay-up system spread effort in the BC halibut fishery. Marine Policy 42:5-13. https://doi. org/10.1016/j.marpol.2013.01.010

Pinkerton, E. 2014. Groundtruthing individual transferable quotas. Pages 109-120 in P. Durrenburger and G. Palsson, editors. Gambling debt: Iceland's struggle with the New World Order. University Press of Colorado, Boulder, Colorado, USA. https:// doi.org/10.5876/9781607323358.c009

Pinkerton, E., and D. N. Edwards. 2009. The elephant in the room: the hidden costs of leasing individual transferable fishing quotas. Marine Policy 33(4):707-713. https://doi.org/10.1016/j.marpol.2009.02.004

Pinkerton, E. W. 1987. Competition among BC fish processing firms. Pages 66-91 in P. Marchak, N. Guppy, and J. McMullan, editors. Uncommon property: the fishing and fish processing industries in British Columbia. Methuen, Toronto, Ontario, Canada. 
Province of British Columbia. 2017. British Columbia seafood industry: year in review 2016. Ministry of Agriculture, Victoria, British Columbia, Canada. https://www2.gov.bc.ca/assets/gov/ farming-natural-resources-and-industry/agriculture-and-seafood/ statistics/industry-and-sector-profiles/year-in-review/ bcseafood_yearinreview_2016.pdf

R Development Core Team. 2019. R: a language and environment for statistical computing. $\mathrm{R}$ Foundation for Statistical Computing.

Ramirez-Sanchez, S., and E. Pinkerton. 2009. The impact of resource scarcity on bonding and bridging social capital: the case of fishers' information-sharing networks in Loreto, BCS, Mexico. Ecology and Society 14(1):22.

Ropicki, A. J., and S. L. Larkin. 2014. Social network analysis of price dispersion in fishing quota lease markets. Marine Resource Economics 29(2):157-176. https://doi.org/10.1086/676852

Shaffer, M. 1979. An economic study of the structure of the British Columbia salmon industry. Report prepared for Fisheries and Oceans Canada, Ottawa, Ontario and the British Columbia Ministry of the Environment, Victoria, British Columbia, Canada. http://science-catalogue. canada. ca/record=3879985\&searchscope $=06$

Sharman, J. C. 2011. Testing the global financial transparency regime. International Studies Quarterly 55(4):981-1001. https:// doi.org/10.1111/j.1468-2478.2011.00693.x

Simpson, I. 2017. Analysis of commercial fishing licence, and quota values (as at December 31, 2016). Report prepared for Fisheries and Oceans Canada, Pacific Region. http://salishseas.ca/wpcontent/uploads/2017/12/2016_Valuation_Study_CMG_REVISED. compressed.pdf

Smith, A. 1776. An inquiry into the nature and causes of the wealth of nations. Printed for Messrs. Whitestone, Chamberlaine, W. Watson, [etc.], Dublin, Ireland.

Stephenson, R. L., M. Wiber, S. Paul, E. Angel, A. Benson, A. Charles, O. Chouinard, D. Edwards, P. Foley, D. Lane, J. McIsaac, B. Neis, C. Parlee, E. Pinkerton, M. Saunders, K. Squires, and U. R. Sumaila. 2018. Integrating diverse objectives for sustainable fisheries in Canada. Canadian Journal of Fisheries and Aquatic Sciences 76(3):480-496. https://doi.org/10.1139/cjfas-2017-0345

Stigler, G. J. 1966. The theory of price. Third edition. Macmillan, New York, USA. https://doi.org/10.2307/2601511

Stiglitz, J. E. 1993. The role of the state in financial markets. World Bank Economic Review 7(suppl_1):19-52. https://doi.org/10.1093/ wber/7.suppl 1.19

Stiglitz, J. E. 2000. The contributions of the economics of information to twentieth century economics. Quarterly Journal of Economics 115(4):1441-1478. https://doi.org/10.1162/003355300555015

Stoll, J. S., C. M. Beitl, and J. A. Wilson. 2016. How access to Maine's fisheries has changed over a quarter century: the cumulative effects of licensing on resilience. Global Environmental Change 37:79-91. https://doi.org/10.1016/j.gloenvcha.2016.01.005

Sumaila, U. R. 2010. A cautionary note on individual transferable quotas. Ecology and Society 15(3):36. https://doi.org/10.5751/ ES-03391-150336
Tanzi, V. 2011. Government versus markets: the changing economic role of the state. Cambridge University Press.

Thompson, S. A., R. L. Stephenson, G. A. Rose, and S. D. Paul. 2019. Collaborative fisheries research: the Canadian Fisheries Research Network experience. Canadian Journal of Fisheries and Aquatic Sciences 76(5):671-681. https://doi.org/10.1139/cjfas-2018-0450

United Fishermen and Allied Workers' Union. 2005. Pilot integration proposal Phase I response to the CGIAC.

van Putten, I., and C. Gardner. 2010. Lease quota fishing in a changing rock lobster industry. Marine Policy 34(5):859-867. https://doi.org/10.1016/j.marpol.2010.01.008

van Putten, I., K. G. Hamon, and C. Gardner. 2011. Network analysis of a rock lobster quota lease market. Fisheries Research 107(1-3):122-130. https://doi.org/10.1016/j.fishres.2010.10.015

Windle, M. J. S., B. Neis, S. Bornstein, M. Binkley, and P. Navarro. 2008. Fishing occupational health and safety: a comparison of regulatory regimes and safety outcomes in six countries. Marine Policy 32(4):701-710. https://doi.org/10.1016/i.marpol.2007.12.003 